\title{
純銅圧延板の再結晶集合組織におよぼす 微量添加元素の影響*
}

\author{
牧田春光 ${ }^{* *}$ 花田修治*** 和泉 修***
}

J.Japan Inst.Metals, Vol.50,No.6(1986),pp.530-537

Effects of 0.1 mol\% Additional Elements on the Recrystallization

Texture of Cold-rolled Pure Copper

Harumitsu Makita**, Shuji Hanada*** and Osamu Izumi***

The rolling texture and the primary and secondary recrystallization texture of copper alloy sheets were measured by $\mathrm{X}$-ray diffraction and electron channeling pattern method. The specimen sheets contain $0.1 \mathrm{~mol} \%$ additional elements such as $\mathrm{Si}, \mathrm{Ge}, \mathrm{P}$, In and $\mathrm{Ti}$.

Deformation textures were not affected by all the additional elements and showed the $\mathrm{Cu}$-type texture. The recrystallization texture was found to fall into two types. In case of $\mathrm{Si}$ or Ge addition, which slightly raised the recrystallization temperature, the primary recrystallization texture showed a sharp cube orientation and the secondary recrystallization appeared. On the contrary, in case of $\mathrm{P}$, In or $\mathrm{Ti}$ addition, which distinctly raised the recrystallization temperature, the primary recrystallization texture showed a weak cube orientation mixed with other orientations and no secondary recrystallization occurred.

The obtained results are discussed in relation to stacking fault energies and grain boundary structures.

(Received December 19, 1985)

Keywords : copper, additional elements, texture, primary recrystallization, secondary recrystallization

\section{I. 緒言}

純銅に極く微量の第 2 元素を添加すると再結晶挙動が大 きく変わることが知られている，たとえば，Liu とRichman (1) (2) は純銅に $\mathrm{Ge}, \mathrm{Sn}, \mathrm{P}, \mathrm{As}$ や Sb を添加した場合に 集合組織が変化することを報告している，また，Liu と Alers ${ }^{(3)}{ }^{(4)}$ はやはり純銅に A1 や Sn を添加した場合につい て集合組織の変化を確認している。 しかし，いずれも圧延 扣よび 1 次再結晶についてのみであり，2 次再結晶まで言 及していない，近年では堀ら ${ }^{(5)}$ 鈴木ら ${ }^{(6)}$-(8)によって純 銅の再結晶温度に及ぼす微量添加元素の影響が多くの元素 について調べられているが，集合組織に関する検討はほと んど見られない.

著者らは最近純銅の再結晶, 特に 2 次再結晶について調 べ, 2 次再結晶が発現する条件を明らかにするとともに， 1 次再結晶集合組織と 2 次再結晶集合組織の方位関係につ いて検討した ${ }^{(9)}$ 。それによれば，2 次再結晶粒の優先成長 方位は 1 次再結晶集合組織と密接に関係していることが示
された，従って，極く微量の添加元素は 1 次再結晶のみで なく，2 次再結晶にも大きな影響を与えると考えられる. そこで, 本研究では純銅に微量元素を添加した場合の圧延 集合組織, 1 次再結晶集合組織および 2 次再結晶集合組織 の変化を系統的に調べることにより，これらの集合組織の 相互の関連性について明らかにすることを目的とした。

\section{II. 実 験 方 法}

堀ら ${ }^{(5)}$ は純銅に微量元素を添加した場合, 添加量 - 再結 晶温度曲線が約 $0.1 \mathrm{~mol} \%$ で飽和する傾向にあることを示 している。また．固溶型と析出型では再結晶機構が異なる と考えられるため, 本研究では固溶型のものについてのみ 着目した，その中で $0.1 \mathrm{~mol} \%$ 添加した場合，再結晶温度 を上昇させる効果の小さい $\mathrm{Si}$ と $\mathrm{Ge}$, 再結晶温度上昇に効 果のある $\mathrm{P}$ In, そして最も効果のある Ti の 5 種類を添 加元素として選んだ。これらの元素を $0.1 \mathrm{~mol} \%$ を目標と して無酸素銅に添加した試料を高周波真空溶解にて作製し た.この時, Si とIn については共晶組成の母合金をアル

\footnotetext{
** 株式会社河合楽器製作所, 現在 : 東北大学金属材料研究所 (Kawai Musical Instruments Mfg. Co., Ltd., Hamamatsu. Present address : The Research Institute for Iron, Steel and Other Metals, Tohoku University, Sendai)

*** 東北大学金属材料研究所 (The Research Institute for Iron, Steel and Other Metals, Tohoku University, Sendai)

* 1985 年 10 月日本金属学会新潟大会に一部発表
} 
Table 1 Impurities of copper used.

\begin{tabular}{c|c|c|c|c|c|c|c|c|c|c|c}
\hline \hline & $\mathrm{Fe}$ & $\mathrm{As}$ & $\mathrm{Sb}$ & $\mathrm{Bi}$ & $\mathrm{Sn}$ & $\mathrm{Ni}$ & $\mathrm{Pb}$ & $\mathrm{Ag}$ & $\mathrm{Si}$ & $\mathrm{O}$ & $\mathrm{P}$ \\
\hline $\begin{array}{l}\text { mol } \\
\mathrm{ppm}\end{array}$ & 9 & 1 & 1 & $<1$ & 1 & 1 & 2 & 5 & 1 & 12 & 4 \\
\hline
\end{tabular}

Table 2 Chemical composition of additional elements.

\begin{tabular}{c|c|c|c|c|c}
\hline \hline & $\mathrm{Cu}-\mathrm{Si}$ & $\mathrm{Cu}-\mathrm{Ge}$ & $\mathrm{Cu}-\mathrm{P}$ & $\mathrm{Cu}-\mathrm{In}$ & $\mathrm{Cu}-\mathrm{Ti}$ \\
\hline $\begin{array}{c}\text { mol } \\
\text { ppm }\end{array}$ & 938 & 1050 & 1014 & 885 & 1007 \\
\hline
\end{tabular}

ゴン雾囲気アーク炉にて溶製してから，Pについては市販 燐銅を用いてそれぞれ所定量を無酸素銅に添加した。

Table 1 には使用した無酸素銅の分析値を, Table 2 に は試料中の添加元素の分析值を示す。ほぼ目標の $0.1 \mathrm{~mol} \%$ が添加されていることがわかる.

この試料を面削後 $1073 \mathrm{~K}$ で $63 \%$ 熱間圧延をした. 空冷 後更に 40\% の冷間圧延をして 823〜 973 K で焼鈍し，平均 結晶粒径を $50 \mu \mathrm{m}$ に揃えた。次に室温で 2 段(板厚 $1 \mathrm{~mm}$ まで，ワークロール径 $250 \mathrm{~mm}$ ) 就よび 4 段圧延機 (ワーク ロール径 $130 \mathrm{~mm}$ ) を用いて約 $99 \%$ の 1 方向圧延を施し,

厚さ $0.1 \mathrm{~mm}$ の板材とした。 これらの板材に対して 4〜6 $\times 10^{-2} \mathrm{~Pa}$ 中 $473 \sim 1313 \mathrm{~K}$ で焼鈍後, マイクロヴィッカー スによる微小硬度の測定, 光学顕微鏡, 走查型電子顕微鏡 による組織観察およびX 線による集合組織の測定を行なっ た. 用いたX 線は $\mathrm{MoK}_{\boldsymbol{c}}$ 線で, Schulz の反射法により $\{100\}$ 極点図を作製した。また，走査型電子顕微鏡エレク トロン・チャネリング・パターン (SEM-ECP)による結晶 方位分布の測定や透過型電子顕微鏡による転位組織の観察 も行なった.

\section{III. 結 果}

まず，室温 $(300 \mathrm{~K})$ から $973 \mathrm{~K}$ までの種々の温度で 7.2 $\mathrm{ks}$ 焼鈍した場合の焼鈍温度と硬度の関係を Fig.1 に示し た。このような高加工度圧延材では, 室温放置でも回復 . 再結晶が進行するため, 室温での測定值にバラッキが見ら れている. しかし，加工集合組織はいずれも純銅型を示

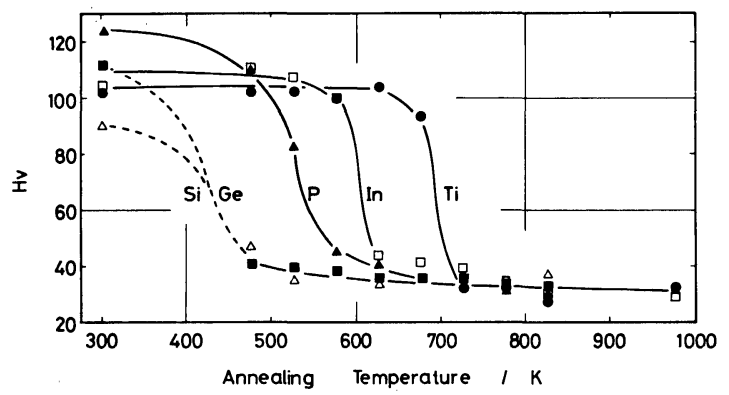

Fig.1 Hardness vs. annealing temperature curves of cold-rolled $\mathrm{Cu}$ with $0.1 \mathrm{~mol} \%$ additional elements. Annealed for $7.2 \mathrm{ks}$ at each temperature after $99 \%$ cold-rolling.

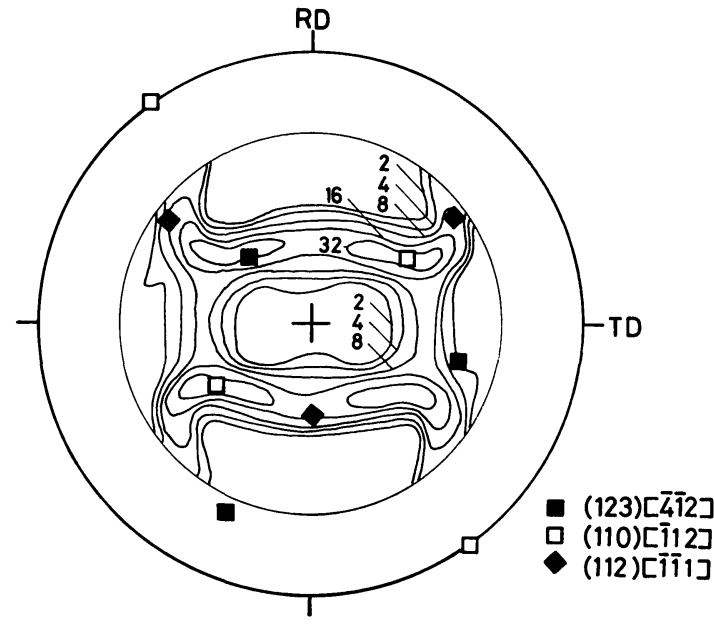

Fig.2 $\{100\}$ pole figure for the rolling texture of $\mathrm{Cu}-\mathrm{Si}$ alloy after $99 \%$ cold-rolling (Tube voltage 40 $\mathrm{kV}$; Tube current $25 \mathrm{~mA}$ ).

し，極点図上での差異はみられなかった，Fig.2 に 1 例と して Si 添加材の $\{100\}$ 極点図を示した。 この極点図は

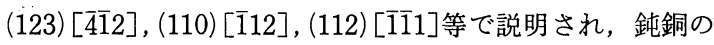
それと同じである。

$473 \mathrm{~K}$ で焼鈍した場合，Si および $\mathrm{Ge}$ 添加材は既に軟化 がほぼ完了している。これに対して P, In および Ti 添加 材では軟化温度が上昇しており，特に Ti 添加材では 673 $\mathrm{K}$ まで高い硬度を維持している。これらの変化は堀ら ${ }^{(5)}$ 鈴木ら ${ }^{(6)}$ の結果と大略一致する。

光学顕砫鏡による組織観察結果は硬度測定結果と良く対 応しており, 軟化した試料ではいずれも 1 次再結晶粒が観 察された. Fig.3 には $723 \mathrm{~K}$ で焼鈍した場合の光学顕微鏡 組織を示した. Si 添加材では粒界が不明瞭な組織中に黒く 腐食された粒と細かい双晶が点在している。これに対し て，その他の試料では粒界が比較的良くわかり，結晶粒内 を貫通している双晶が観察される。 また Ti 添加材では, 硬度測定結果では再結晶が完了しているものの, 組織では まだ未再結晶領域が残っているようである。そこで $773 \mathrm{~K}$ で焼鈍した場合の $\{100\}$ 極点図を Fig.4(a)〜 (e) に示し た.この 1 次再結晶集合組織では, 添加元素により大きな 差異がみられている。すすおち，これらは鮮鋭な立方体方 位が発達する $\mathrm{Si}, \mathrm{Ge}$ 添加材と立方体方位が抑制される $\mathrm{P}$, In および Ti 添加材に大別される，前者は純銅に対して再 結晶温度があまり，あるいはほとんど上昇していない材料

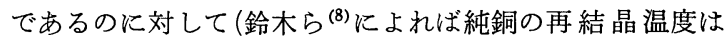
約 $440 \mathrm{~K}$ である), 後者は再結晶温度が顕著に上昇した材 料といら点で共通点がみられる. 本実験に限っていうな ら, 再結晶温度を上昇させる効果のある添加元素は立方体 方位を抑える効果があることを示している.

これらの試料を更に高温で焼鈍したところ, Si 添加材で は $1273 \mathrm{~K}$ 以上, $\mathrm{Ge}$ 添加材では $1073 \mathrm{~K}$ 以上で 2 次再結晶 が発現し, 約 $20 \mathrm{~mm} \times 20 \mathrm{~mm} \times 0.1 \mathrm{~mm}$ の試料が 1 個ある 

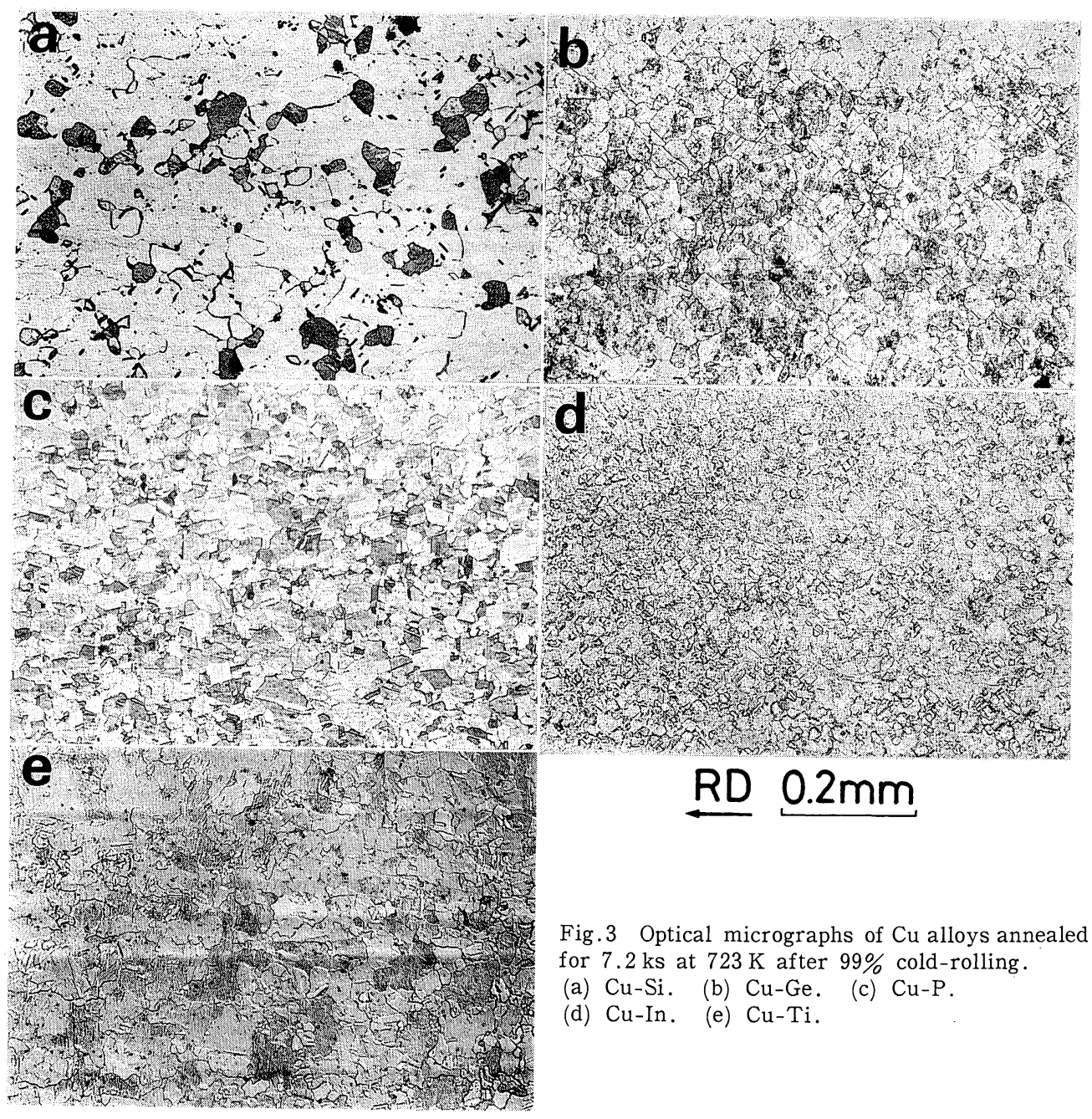

\section{$\underline{\mathrm{RD}} \underline{0.2 \mathrm{~mm}}$}

いは数個の結晶粒となることがわかった，そこで， $\mathrm{Si}$ 添加 材について焼鈍温度をかえた場合の光学顕微鏡組織観察と $\{100\}$ 極点困の測定を括こなった。結果を Fig.5 (a)〜 (f) と 示した. 光学顕微鏡観察より,黒い粒と細かな双晶は焼鈍温 度の上昇とともに消減することがわかる．また $\{100\}$ 極点 図では焼鈍温度の上昇とともに立方体方位(ゴーストを含 む) 以外の方位が消減し，立方体方位の分散も小さくな る結果, R.P.N. (Rolling Plane Normal)の強度が上昇し ている，このことより，この黒い粒は立方体方位以外の方 位をもっていると考号れる。

次に, この $\mathrm{Si}$ 添加材の 1 次再結晶状態を更に詳細に検 討するため, $723 \mathrm{~K}$ および $1173 \mathrm{~K}$ で焼鈍した試料を腐食 後走查型電子顕微鏡で観察した．Fig. $6(\mathrm{a}) \sim(\mathrm{c})$ 亿組織抒 よび SEM-ECP による結晶方位分布測定結果を $\{100\}$ 極 点図で示した， $723 \mathrm{~K}$ で焼鈍した試料では，大部分が立方 体方位を示しているがそれ以外の方位をるつ粒があること がわかる，写真(a) と対応させた結果，立方体方位以外の 方位をもつ粒は写真中では矢印で示したように周囲の粒に 対して深く腐食された凹粒であることがわかった，更に
Fig.3 Optical micrographs of $\mathrm{Cu}$ alloys annealed for $7.2 \mathrm{ks}$ at $723 \mathrm{~K}$ after $99 \%$ cold-rolling.
(a) $\mathrm{Cu}-\mathrm{Si}$.
(b) $\mathrm{Cu}-\mathrm{Ge}$.
(c) $\mathrm{Cu}-\mathrm{P}$.
(d) $\mathrm{Cu}-\mathrm{In}$.
(e) $\mathrm{Cu}-\mathrm{Ti}$.

これは,Fig.5 (a)〜 (c) では黒い粒に相当していることが 確認された。この凹粒についてのみ結晶方位を測定した結 果が Fig.6(c)である.Fig.6(c)にみられる集積はX線で も検出されており (Fig.4(a), Fig.5(d)〜 (f)), 大略 (135) [475] ]で表わされる。 このような, 立方体方位とその双晶 方位以外の方位の出現は合金型集合組織への遷移が始まっ ていることを示していると考兄らる。ささらに，これらの 結果より Fig. 4(a) と Fig.5(d)〜 (f) で立方体方位と (135) [475] 以外がゴーストであると考劣られる．これらの解析 結果をFig.4(a)にまとめて示した.ここで，Fig.4(a) と Fig.5 (d) は同一処理材であるが，後者には前者では検出さ れていないピークがある，このことからもこれらの検出さ れていないピークはゴーストであると考えられたけ。

$1173 \mathrm{~K}$ で焼鈍した試料 (Fig.5 (c)) では大部分の粒が立方 体方位から $0.140 \mathrm{rad}\left(8^{\circ}\right)$ 以内の方位を示し，わずかに凹 粒が観察されるのみであった。しかしきわめて稀ではある

$†$ Fig.4 と Fig. 5 は測定条件が異なるためX線強度単 位が異なる。しかし，いずれにおいても低強度レべ ルのピークはすべて検出されている. 

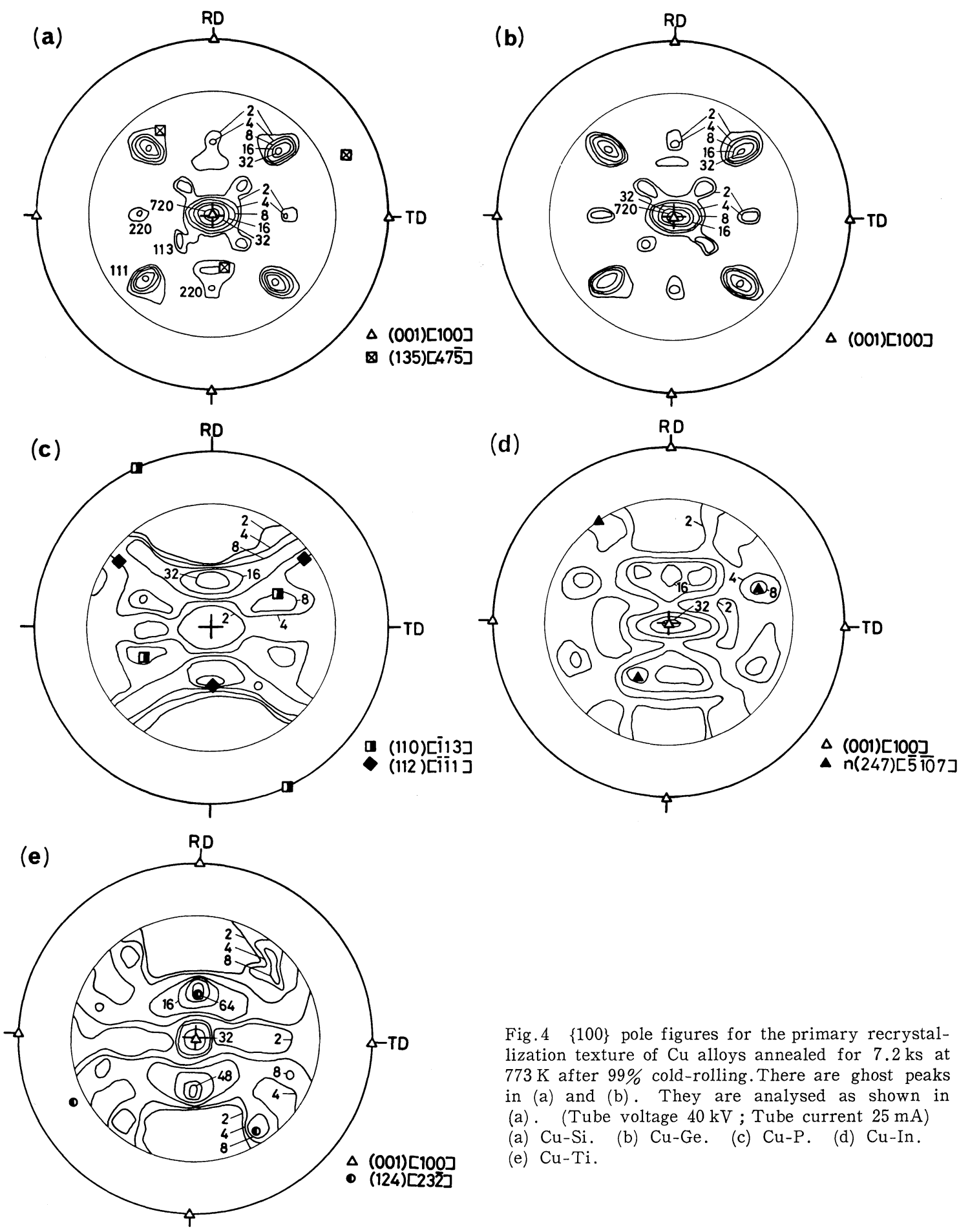

Fig. $4\{100\}$ pole figures for the primary recrystallization texture of $\mathrm{Cu}$ alloys annealed for $7.2 \mathrm{ks}$ at $773 \mathrm{~K}$ after $99 \%$ cold-rolling. There are ghost peaks in (a) and (b). They are analysed as shown in (a). (Tube voltage $40 \mathrm{kV}$; Tube current $25 \mathrm{~mA}$ )

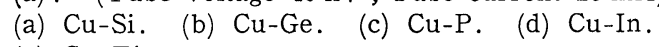
(e) $\mathrm{Cu}-\mathrm{Ti}$.

が立方体方位から $0.174 \sim 0.262 \operatorname{rad}\left(10^{\circ} \sim 15^{\circ}\right)$ 離れた方 位が観察され, そのような方位は次に示す 2 次再結晶粒の 方位と大略一致するような結果が得られた。.Fig.6(b) に実 線で示した観察例は，立方体方位を〈100>軸まわりに $0.209 \sim 0.227 \mathrm{rad}\left(12^{\circ} \sim 13^{\circ}\right)$ 回転した方位である.

$\mathrm{P}, \mathrm{In}$ および $\mathrm{Ti}$ 添加材では, 1 次再結晶後立方体方位
が強く抑制され，特に $\mathrm{P}$ 添加材では全く検出されない，P 添加銅については Phillips ら (10) や鈴木ら (11)の報告があ る. 鈴木らは $\mathrm{P}$ 添加量が $0.04 \mathrm{~mol} \%$ 以上では $95 \%$ 以下の 圧下率で立方体方位が無視できる程度の微弱方位となるこ とを示している。 しかし，InやTiを添加した場合につい ての報告はみあたらない. In や Ti は $0.1 \mathrm{~mol} \%$ 程度の添 

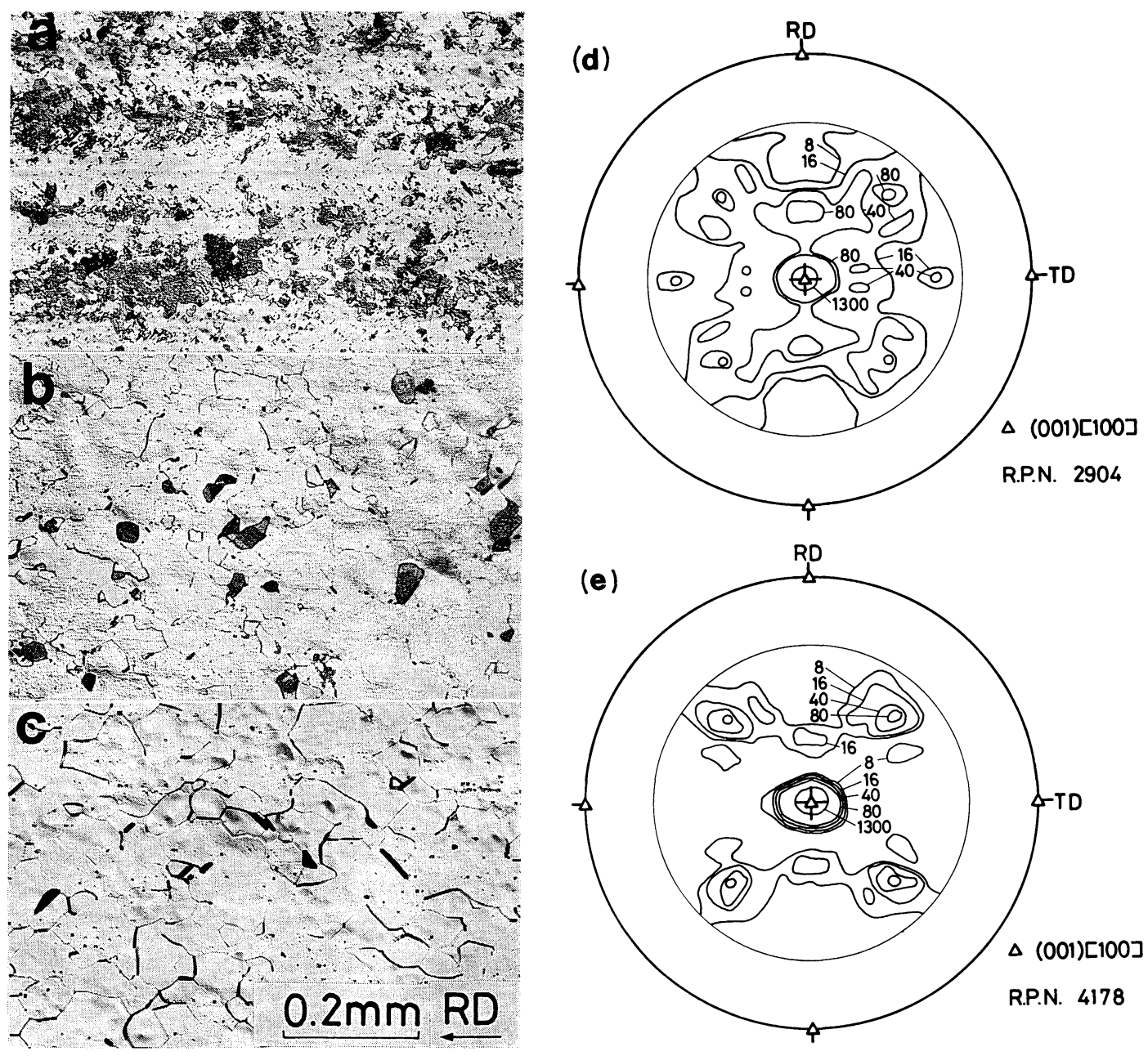

Fig.5 Optical micrographs and their $\{100\}$ pole figures of $\mathrm{Cu}-\mathrm{Si}$ alloy annealed for 7.2 $\mathrm{ks}$ at each temperature after 99\% coldrolling. There are ghost peaks in $\{100\}$ pole figures.
(a) , (d) $473 \mathrm{~K}$.
(b), (e) $773 \mathrm{~K}$.
(c), (f) $1173 \mathrm{~K}$.

$\mathrm{k}$; Tube current $20 \mathrm{~mA}$ )

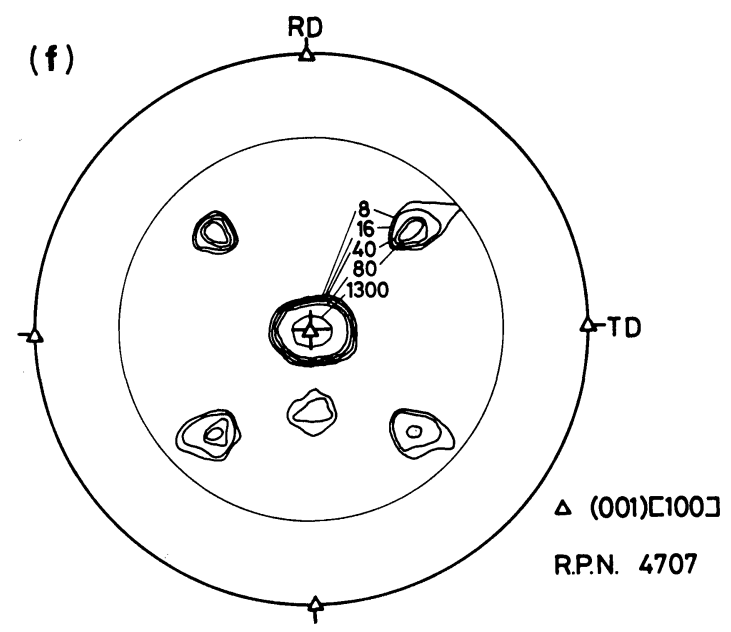

加でも立方体方位を抑制する効果のあることがわかった．

$\mathrm{Si}$ 扰よび $\mathrm{Ge}$ 添加材でみられた 2 次再結晶粒の結晶方位 分布を $\{100\}$ 極点図で Fig.7 (a), (b)飞示した. いずれも 高加工度圧延によって生じる幅方向両端の数 $\mathrm{mm}$ の耳に相 当する部分を除いた場合の結果を主にしている。(a) $\mathrm{Si}$ 添加材の結果で, 試料 15 枚中 7 枚が 2 次再結晶しており， その 2 次再結晶粒は立方体方位に対して $<100>$ 軸まわり $0.157 \sim 0.279 \operatorname{rad}\left(9^{\circ} \sim 16^{\circ}\right)$ 回転した方位をもっている. ここで，この方位粒は 1 次再結晶粒中に既に存在している ことをFig.6(b)で確認している. Fig.7 (b) は Ge 添加材 

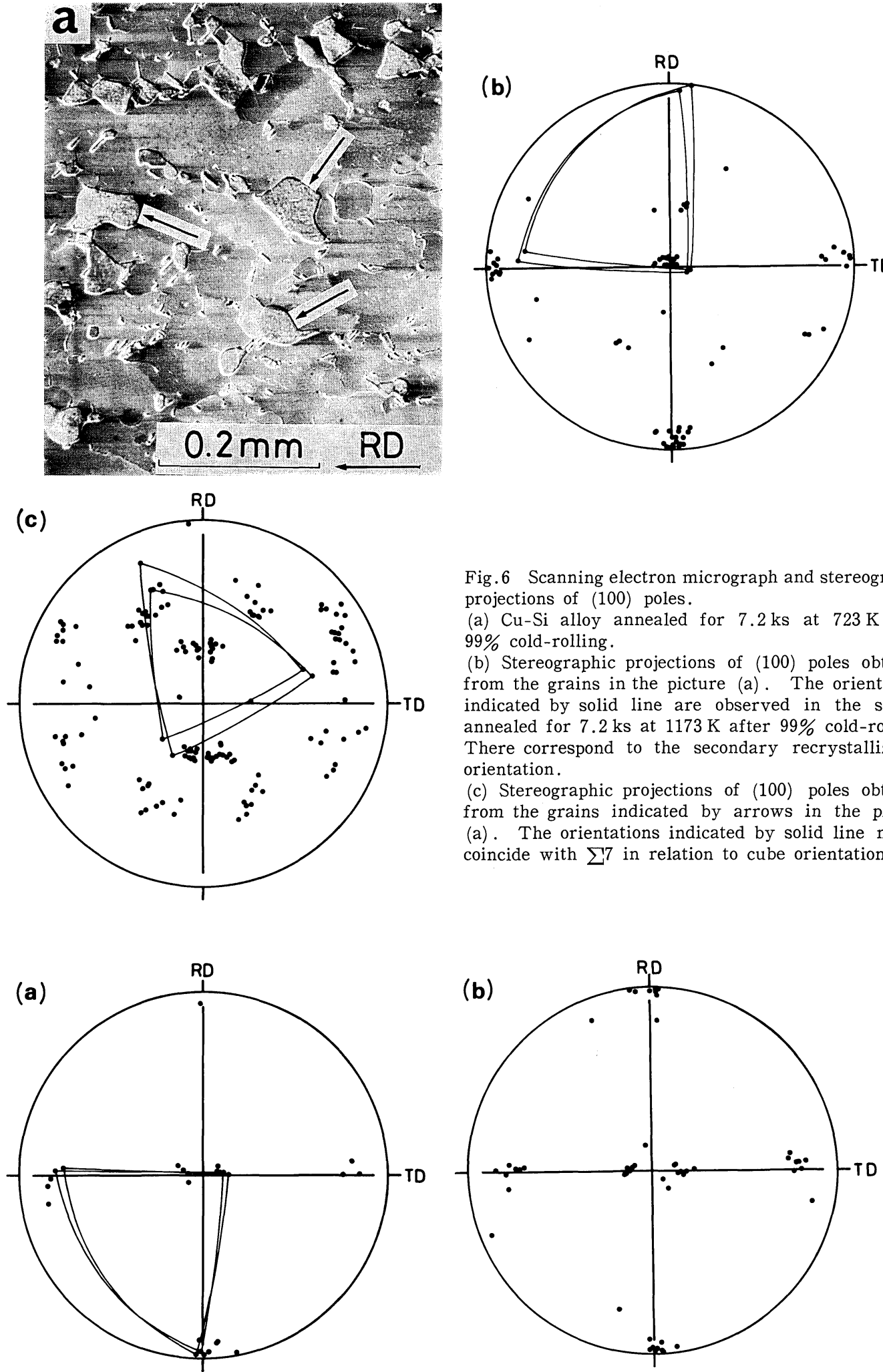

Fig.6 Scanning electron micrograph and stereographic projections of (100) poles.

(a) $\mathrm{Cu}-\mathrm{Si}$ alloy annealed for $7.2 \mathrm{ks}$ at $723 \mathrm{~K}$ after 99\% cold-rolling.

(b) Stereographic projections of (100) poles obtained from the grains in the picture (a). The orientations indicated by solid line are observed in the sample annealed for $7.2 \mathrm{ks}$ at $1173 \mathrm{~K}$ after $99 \%$ cold-rolling. There correspond to the secondary recrystallization orientation.

(c) Stereographic projections of (100) poles obtained from the grains indicated by arrows in the picture (a). The orientations indicated by solid line nearly coincide with $\Sigma 7$ in relation to cube orientation.

Fig.7 Stereographic projections of (100) poles obtained from the secondarily recrystallized grains. Annealed for $3.6 \mathrm{ks}$ at $1313 \mathrm{~K}$ after $99 \%$ cold-rolling. The orientations indicated by solid line were found in the sample annealed with ear.

(a) $\mathrm{Cu}-\mathrm{Si}$. (b) $\mathrm{Cu}-\mathrm{Ge}$. 


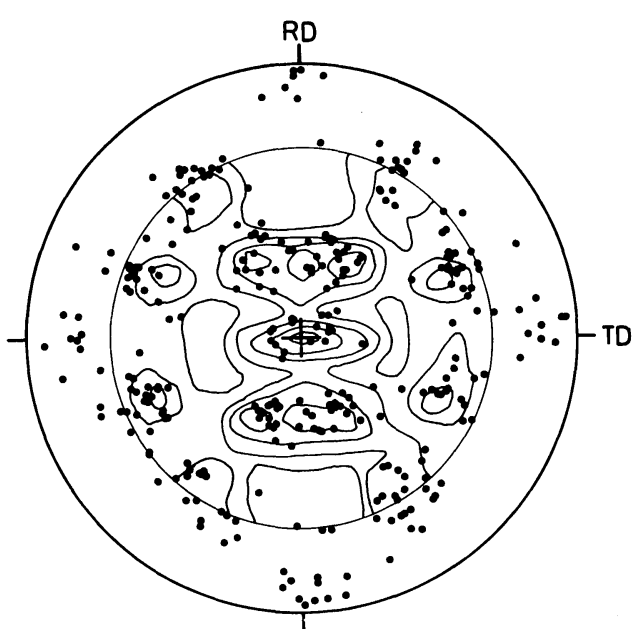

Fig. 8 Stereographic projections of (100) poles obtained from the grains of $\mathrm{Cu}$-In alloy annealed for 3.6 $\mathrm{ks}$ at $1313 \mathrm{~K}$ after $99 \%$ cold-rolling. The pole figure is identical to Fig.4(d). Secondary recrystallization cannot be detected.

の結果で 18 枚の試料すべてが 2 次再結晶し，ほとんどの 方位が立方体方位に対して $<100>$ 軸まわり $0.157 \sim 0.436$ $\operatorname{rad}\left(9^{\circ} \sim 25^{\circ}\right)$ 回転した方位となっている。これらは Si 添 加材の場合に較べて分散がわずかに大きいが，大略同じ方 位と考觉られる。

$\mathrm{Si}$ および Ge のこのような結果に対して，P，In および $\mathrm{Ti}$ 添加材では $1313 \mathrm{~K}$ での焼鈍でも通常の粒成長がみられ るのみであった. Fig.8 にはIn 添加材の SEM-ECP 観察 結果を 1 次再結晶集合組織の極点図とともに示した。 これ 上り結晶方位分布にほとんど変化が扰こっていないことが わかる。

\section{IV. 考察}

$\mathrm{Ge}^{(1)}, \mathrm{P}^{(2)}$ や $\mathrm{Zn} \mathrm{n}^{(3)}$ を純銅飞添加した場合，加工集合組織 が純銅型から黄銅型飞変化しはじめる添加量がそれぞれ $1.0 \mathrm{~mol} \%, 0.43 \mathrm{~mol} \%, 3.8 \mathrm{~mol} \%$ といわれている. 従っ て, $0.1 \mathrm{~mol} \%$ 程度の添加で加工集合組織に変化がみられ なかったといら本実験結果は，従来の結果と照らし合わせ ても妥当なものと考兄られる.

これに対して，1 次再結晶集合組織は添加量に敏感にな る傾向にある．たとえば， $\mathrm{Ge}^{(1)}$ では $0.20 \mathrm{~mol} \%$ 添加で立 方体方位 (その双晶を含む) 以外の方位が出現しはじめ, $\mathrm{P}(11)$ では $0.02 \mathrm{~mol} \%$ 添加で立方体方位が抑制されるとい われている。しかし本実験では Ge $0.1 \mathrm{~mol} \%$ 添加でも立 方体方位以外の方位が観察された。

このように添加元素によって集合組織が変化する原因と して積層欠陥エネルギーの変化が考兄らている. 光学顕 微鏡による 1 次再結晶後の組織観察で (Fig. 3) 双晶形態に 大きな違いがみられ，やはりこれが 1 次再結晶集合組織の 差異に関係しているように思われる。すむなわち， Si 添加
材に怙いては白い地中に細かい双晶が見られるが，これは 圧延方向に対して約 $0.785 \mathrm{rad}\left(45^{\circ}\right)$ 傾いて括り, 立方体方 位の双晶 ${ }^{(12)}$ と考光られる。 その他のものについても粒内を 貫通した大きな双晶が数多く観察されるが，Ge 添加材で は圧延方向に対して約 $0.785 \mathrm{rad}\left(45^{\circ}\right)$ 傾いた立方体方位の 双晶が大部分であるのに対し，P, In および Ti 添加材で は双晶方向はランダムである，さらに Fig.5 (a)～(c) で示 した通り，双晶(頻度)は焼鈍温度にも依存し， Si 添加材， $\mathrm{Ge}$ 添加材いずれも2 次再結晶直前の温度で焼鈍した場合 には双晶が皃とんどみられなくなる。これに対し $\mathrm{P}$, In よび Ti 添加材では, $1313 \mathrm{~K}$ で焼鈍しても双晶が数多く又 られるといら共通点がみられた．純銅においても燒鈍温度 が高くなると双晶はみられなくなり，立方体方位への集積 が高まることが確認されている(13)．このよらに微量元素 の添加による積層欠陥エネルギーの变化とともに, 積層欠 陥エネルギーの温度依存性 ${ }^{(12)}$ も2 次再結晶出現の有無と 関連していると考兄られた。

添加元素による積層欠陥エネルギーの変化を直接測定す る方法として，X線や透過型電子顕微鏡を用いた方法が確 立されている(14)-(16)．そこでIn 添加材の加工拈よび 673 $\mathrm{K}-7.2 \mathrm{ks}$ 焼鈍材の (111) 扐よび (200) X線回折角 $(2 \theta)$ を測 定したが(15)，回折角の移動は観察されなかった。ささらに $\mathrm{Si}$ 添加材および In 添加材を室温で約 10\% 圧延後透過型 電子顕微鏡で転位組織を観察したが，いずれもセル構造を 示し両者の間に相異がみられなかった。添加量が少ないゆ えに, いずれの方法に沶いて子積層欠陷汇関する情報が得 られなかったものと考觉らる。

2 次再結晶に扰いてはさらに隣接粒の方位関係も重要で ある.Fig.9 はFig.6 と Fig.8のデータを隣接粒の対応 格子関係についてまとめたるのである.いずれる 1 次再結 晶状態での測定結果であるが，Si 添加材では低角度粒界が 大部分であるのに対し，In 添加材では低角度粒界の割合

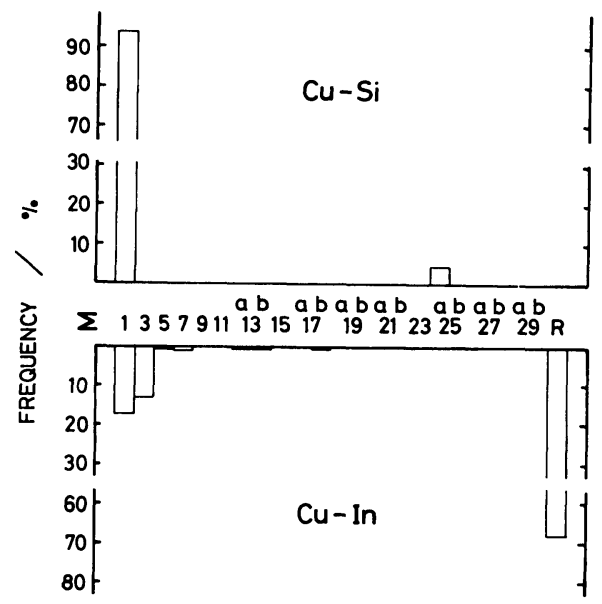

Fig.9 The frequency of grain boundaries after primarily recrystallized grains as a function of $\Sigma$ values. 


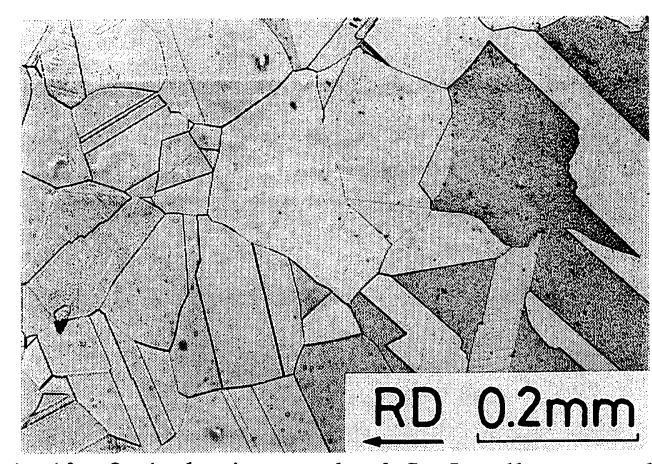

Fig.10 Optical micrograph of $\mathrm{Cu}$-In alloy annealed for $7.2 \mathrm{ks}$ at $1173 \mathrm{~K}$ after $99 \%$ cold-rolling.

が小さくランダム粒界の割合が増大している．Fig.10 に は In 添加材を $1173 \mathrm{~K}$ で焼鈍した場合の 1 次再結晶状態 での光学顕微鏡組織を示した。 Si 添加材を同一条件で焼鈍 した場合 $(F i g .5(\mathrm{c}))$ と較べて，In 添加材では結晶粒が成長 している。これは低角度粒界の方がランダム粒界より移動 しにくいことを示している。このような粒界構造の違いが 2 次再結晶挙動に大きな影響をおよぼしている。また，珪 素鋼などに打いて 2 次再結晶を発生させるためのインヒビ ターとして重要な働きをしている $\mathrm{MnS}$ 等の役目をこの低 角度粒界が果たしていると考兄られる。

次に，2 次再結晶でみられた方位について検討する．著 者らは, 純銅の初期結晶粒径が約 $50 \mu \mathrm{m}$ の素材に 1 方向圧 延を施し，耳を除いて焼鈍すると，得られる 2 次再結晶粒 は立方体方位に対して 237 の方位が大部分であることを 報告した ${ }^{(9)}$. 一方, 今回の $\mathrm{Si}$ 添加材扰よび $\mathrm{Ge}$ 添加材で 得られた 2 次再結晶粒は立方体方位に対してやはり $\Sigma 37$ の方位関係をすつ粒が大部分であった。このことは，Si 添 加材や $\mathrm{Ge}$ 添加材に执いて子 1 次再結晶集合組織と 2 次再 結晶集合組織の間には，純銅の場合と同様に密接な方位関 係が保たれていることを示している。

\section{V. 結 論}

純銅に Si, Ge, P, In および゙ Ti を $0.1 \mathrm{~mol} \%$ 添加した 場合の加工および再結晶集合組織を調べ次の結論を得た。

（1）加工集合組織はいずれも純銅型を示し，(123）[41ㅜ2]， (110) [1112], (112) [1̄111]等で表わされる.

（2）純銅に対して再結晶温度を上昇させる効果の小さい

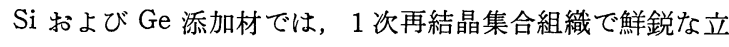
方体方位が発達するのに対して，再結晶温度を上昇させる 効果の大きい $\mathrm{P}, \mathrm{In}$ および Ti 添加材では 1 次再結晶集合 組織で立方体方位が抑制される。
（3） Si および Ge 添加材では鮮鋭な立方体方位中に立方 体方位以外の方位がわずかに観察された。焼鈍温度が高く なるとこの方位は消光，それとともに立方体方位の分散も 小さくなる結果，立方体方位の集積が高まる。

（4） P 添加材の 1 次再結晶集合組織では立方体方位は検 出されない. In および $\mathrm{Ti}$ 添加材ではわずかに立方体方位 がみられるが, Si 添加材や $\mathrm{Ge}$ 添加材に較べて集積がはる かに低い.

(5) Si 添加材および Ge 添加材では 2 次再結晶がみられ たのに対して，P, In および Ti 添加材では 2 次再結晶は みられない，このことから，鮮鋭な 1 次再結晶集合組織が 発達しない限り 2 次再結晶は発現しないといえる.

(6) Si 添加材に扣いては，その 1 次再結晶粒中に 2 次再 結晶粒と同様の方位をるつ粒が存在していることを確認し た。

終りに, 試料作製においては東北大学金属材料研究所 渡辺貞夫氏に多大な御協力をいただきました。また，X線 測定では東北大学電気通信研究所 宮本信雄教授, 相原政志 助手および赤間洋助技官に多くの御協力を賜わりました. ここに記して感謝の意を表します。また，本研究に対して 有益な議論および助言をして下さった㧣河合楽器製作所 福田 弘氏に謝意を表します。

\section{文献}

(1) Y.C.Liu and R.H.Richman : Trans. AIME, 218 (1960), 688.

(2) R.H.Richman and Y.C.Liu : Trans. AIME, 221 (1961) , 720.

(3) Y. C. Liu and G.A. Alers: Trans. AIME, 236 (1966), 489.

(4) Y.C.Liu and G.A.Alers:Trans. AIME, 245 (1969), 1857.

（5）堀 茂德, 田井英雄, 片山博彰: 日本金属学会誌, 45 (1981), 1223.

（6）鈴木 寿, 菅野幹宏, 前田貴雄 : 日本金属学会誌, $47(1983), 794$.

（7）鈴木 寿, 菅野幹宏, 前田貴雄: 日本金属学会誌, $48(1984), 209$.

（8）鈴木 寿, 菅野幹宏, 大迫敏行 : 日本金属学会誌, $48(1984), 854$.

（9）牧田春光, 花田修治, 和泉 修: 日本金属学会誌, 49(1985), 1027.

(10) V.A.Phillips and A.Phillips : J.Inst.Metals, 81 (1952), 185.

（11）鈴木敬治郎, 上田喜三郎, 辻 正博 : 塑性と加工, 21 (1980), 961.

(12) Hsun $\mathrm{Hu}$ and S.R.Goodman : Trans. AIME, 227 (1963), 627 .

(13) 著者ら: 未発表.

(14) 中島耕一：日本金属学会会報, 5(1966)，149.

(15) B. E. Warren and E. P. Warekois : Acta Met., 3 (1955), 473 .

（16）幸田成康：日本金属学会会報，5(1966)，146. 